\section{EMBRYRIDDLE \\ Aeronautical University}

SCHOLARLY COMMONS

\section{International Journal of Aviation,} Aeronautics, and Aerospace

\title{
An Oasis in the Hospital Desert - General Aviation Meets Medicine
}

Ariel Braverman

American Public University, ariel.bravermann@gmail.com

Follow this and additional works at: https://commons.erau.edu/ijaaa

Part of the Health Services Research Commons, International Public Health Commons, and the Operations and Supply Chain Management Commons

\section{Scholarly Commons Citation}

Braverman, A. (2019). An Oasis in the Hospital Desert - General Aviation Meets Medicine. International Journal of Aviation, Aeronautics, and Aerospace, 6(4). https://doi.org/10.15394/ijaaa.2019.1384

This Position Paper is brought to you for free and open access by the Journals at Scholarly Commons. It has been accepted for inclusion in International Journal of Aviation, Aeronautics, and Aerospace by an authorized administrator of Scholarly Commons. For more information, please contact commons@erau.edu. 
"... One mile of the highway will take you one mile, but one mile of the runway will take you anywhere..." (Unknown author)

\section{Introduction}

General aviation has been a part of rural life almost everywhere in the world. However, in context with medicine, it is usually limited to emergency medical retrieval or long-range transport and rarely in the context of accessibility of medical service.

The problem of access to medical services - primary and emergency medicine in rural areas of the United States is not a new phenomenon. Significant urbanization during recent years increased the workload on urban medical systems but at the same time reduced economic incentive to maintain rural medical facilities. Closure of many rural medical facilities created a situation known as Hospital Desert. The term Hospital Desert defines a community which is located more than 30 miles (or 60 minutes driving) from a medical facility that offers emergency care, but in case of non-emergency medicine and especially in case of less common medical specialties, it can be even more challenging (Bearak, 2017). Sixteen percent of the U.S. mainland meets this definition, including zones that might surprise some Americans. Based on Chartis Center for Rural Health data - more than half of rural hospitals are under threat of closure. Despite the fact, that now people start to move back from the metro to rural areas (Frey, 2018); this backflow does not bring any relief to the areas, rural health systems are still struggling to survive, and there is a need to look for new solutions. Using aviation in making medical care accessible can be one of the solutions. For creating a baseline for discussion and understanding the existing situation, it is essential to examine two systems - Soviet Medical Aviation system (which practically not exist anymore) and Australian Royal Flying Doctor service which serve remote areas of the country.

\section{Soviet Medical Aviation System}

\section{Two Systems as a Basis}

In the early 1950s in the Soviet Union, many rural areas and even some small cities, especially in arctic and tundra areas, were isolated from the world and aviation was the only lifeline of those communities. Provision of medical services was a significant part of this aerial operations - even that such places had a small clinic with usually one doctor - complicated cases were transported by medical aviation (Sanitarnaya Aviacia - Санитарная авиация RUS) to relatively bigger and better equipped regional hospitals. Doctors, who served in such remote clinics, were assigned there by order, usually immediately after completion of medical school and thus, their professional level was usually low, and efficiency of medical care and patient outcomes were strongly dependent on diagnosis and 
aviation retrieval. Today, it is difficult to bring qualified medical personnel to work in remote rural areas except by a large amount of money (as a salary) or with an option to keep urban living by using aviation.

\section{Australian Royal Flying Doctors}

Australian Royal Flying Doctors Service (RFDS) is almost 100 years old. Vast distances between rural communities and major cities created a significant challenge for the Australian medical community in terms of service provision, and aviation answered this. RFDS provides emergency medical retrieval services but also "fly-in fly-out" General Practitioner (GP) and Nurse Clinics. In other words RFDS bring Medicine to the rural communities instead of having them drive many miles to be seen by the doctor (Gardiner, 2017).

\section{"Fly-In" Clinics}

Imagine yourself as a thriving big city ear-nose-throat specialist, urologist, or pediatric ophthalmologist, and you have an opportunity to expand your practice once or twice a week into rural areas, however, with the same working hours and without driving hours and hours (Gruca, 2016) and without moving yourself and your family anywhere. You can start your working day at 8:00 and to finish it at 18:00 but in this period you visit two or three remote clinics, spending maximum of 2-3 hours in total in the aircraft between sites and on the way home. It is much cheaper and simpler to build and to maintain runways than to keep good doctors in remote areas.

Everything can be started by mapping the needs - epidemiological research of a specific area can give us a picture of the medical needs. The way to fulfill these needs will be based not by pushing medical personnel to live there but by mapping available runways and creating medical centers in the airports - "FlyIn Clinics."

To provide an example, we may use state like Arizona, which is average in most demographic variables. See Figure 1. 

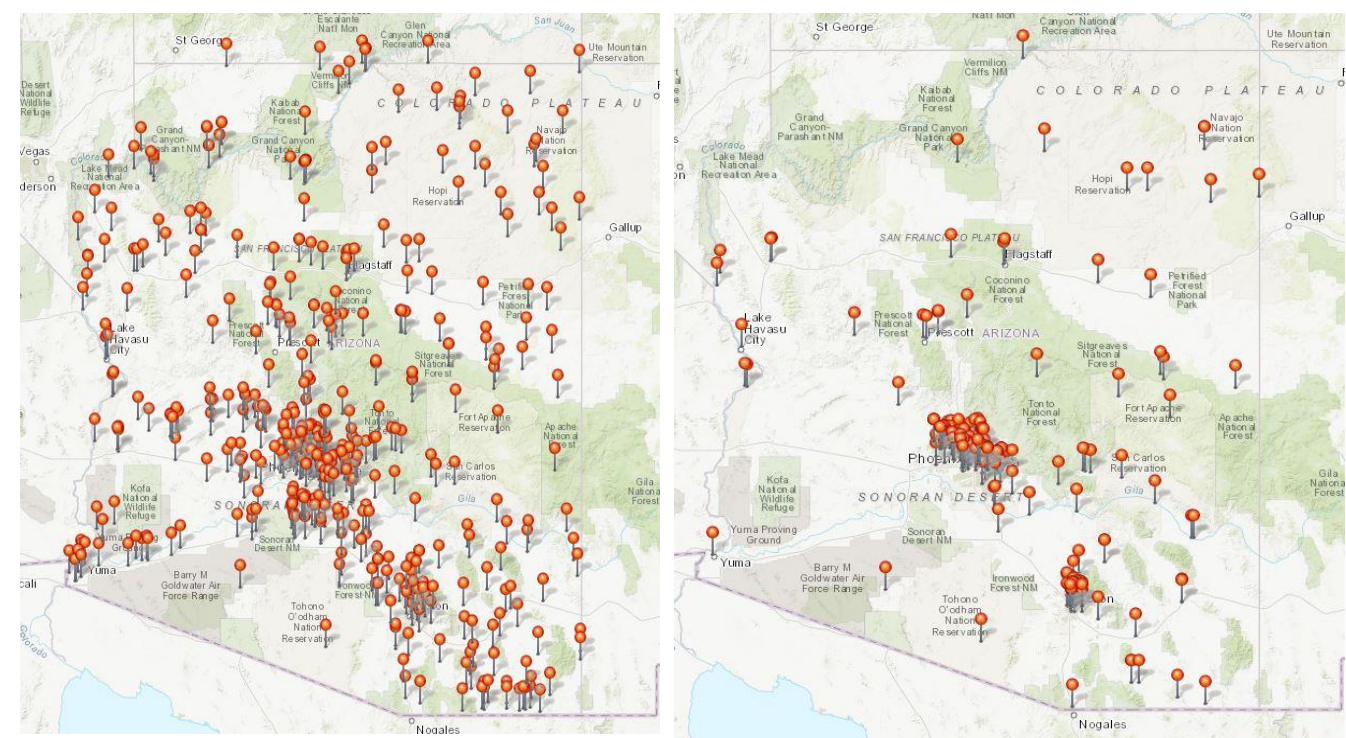

Figure 1. Hospitals and airports in Arizona. Adapted from "Arizona," by Datausa, n.d.

On the right, this is a map of Arizona and every dot in this map marking a hospital or primary clinic, and on the left, this is the same map but with airports. Differences in distribution are pretty obvious. Everything in this map is within one hour of flying on a business jet and about two hours of flying on light piston aircraft (such as a Piper Seneca or Diamond Twin) and every airport is a potential fly-in medical center. Such center will have all necessary equipment based of the level of care and can be managed by a team of two-three people (nurses and nonmedical management staff) and will manage the schedule of GP and specialist visits to fulfill community needs. Appointments and workload management can be done by the internet-based system - in other words - family in a remote farm in north Arizona can have GP from Phoenix who can refer them to a specialist from Tucson - but physically they will be seen in the small airport not far from their farm. Those Fly-In clinics are also can become meeting points between community ambulances and fixed or rotor wing aircraft in cases of emergency and panned aeromedical transport. 
The U.S. Department of Health and Human Services (n.d.) database shows that most of the state is underserved from a medical services point of view but to emphasize the magnitude of the shortage, let us take a look on a physicianpopulation ratio from 2015 and non-metro areas are in significant deficit. See Figure 2.

\begin{tabular}{lll|} 
Arizona & Metro & 23 \\
Arizona & Nonmetro & 8 \\
& & \\
& & Doctors of Medicine (MDs) per \\
Location & Metro/ Nonmetro & $\mathbf{1 0 , 0 0 0}$ People, 2014 \\
$\checkmark$ & $\checkmark$ & 7 \\
Apache County & Nonmetro & 9 \\
Cochise County & Metro & 25 \\
Coconino County & Metro & 9 \\
Gila County & Nonmetro & 6 \\
Graham County & Nonmetro & 6 \\
Greenlee County & Nonmetro & 6 \\
La Paz County & Nonmetro & 24 \\
Maricopa County & Metro & 13 \\
Mohave County & Metro & 10 \\
Navajo County & Nonmetro & 35 \\
Pima County & Metro & 4 \\
Pinal County & Metro & 7 \\
Santa Cruz County & Nonmetro & 17 \\
Yavapai County & Metro & 12 \\
\hline Yuma County & Metro & \\
& & \\
\hline
\end{tabular}

Figure 2. Physician to population ratio in 2015. Adapted from "Visualization," by Rural Health Hub, 2019. 
However, does Arizona a unique case? Based on national data, physicianpopulation ratio (per 10,000 people) is slightly better, but yet, non-metro areas are significantly underserved. See Figure 3.

United States $\quad$ Metro 30

United States Nonmetro $\quad 11$

Figure 3. U.S. nation physician to population ratios for 2015. Adapted from "Visualization," by Rural Health Hub, 2019.

To summarize, it will be correct to state that most of rural USA is medically underserved, and aviation base medical system may create a feasible and cost-efficient solution.

\section{Management and Operations}

Effective management of medical and aviation systems combination demands several building blocks:

Medical staff - medical personnel can come from one or several tertiary medical center's staff - doctors and nurses. Such "fly-days" can be a great benefit to break a working routine in the hospital.

Aircraft operator -In the US, it can be any FAR Part 135 operator (Air Taxi) and in case of medical retrieval AC-135-15. The important point is that in case of only moving medical personnel from point to point, there is no need for specialized aircraft.

Financing - this is the most critical issue of the discussion because aviation is a costly industry, but so is Medicine. If we will put together money savings from early diagnosis which will reduce a treatment costs, and if we will compare salary that can bring a permanently skilled physician to remote rural 
areas, we will see, that such day trips will be much less expensive. Operating cost of pressurized, six seats Pilatus PC-12 aircraft (primary aircraft of RFDS in the picture below) is around 1000 USD for 300nm mission (see Figure 4). To compare, simple appendectomy operation costs around 30,000 USD on average. The economic incentive for insurance companies for bringing medical care to reduce complications can be a good research topic for healthcare economist, but the first look on the numbers shows that such operations can save a lot of insurance money.

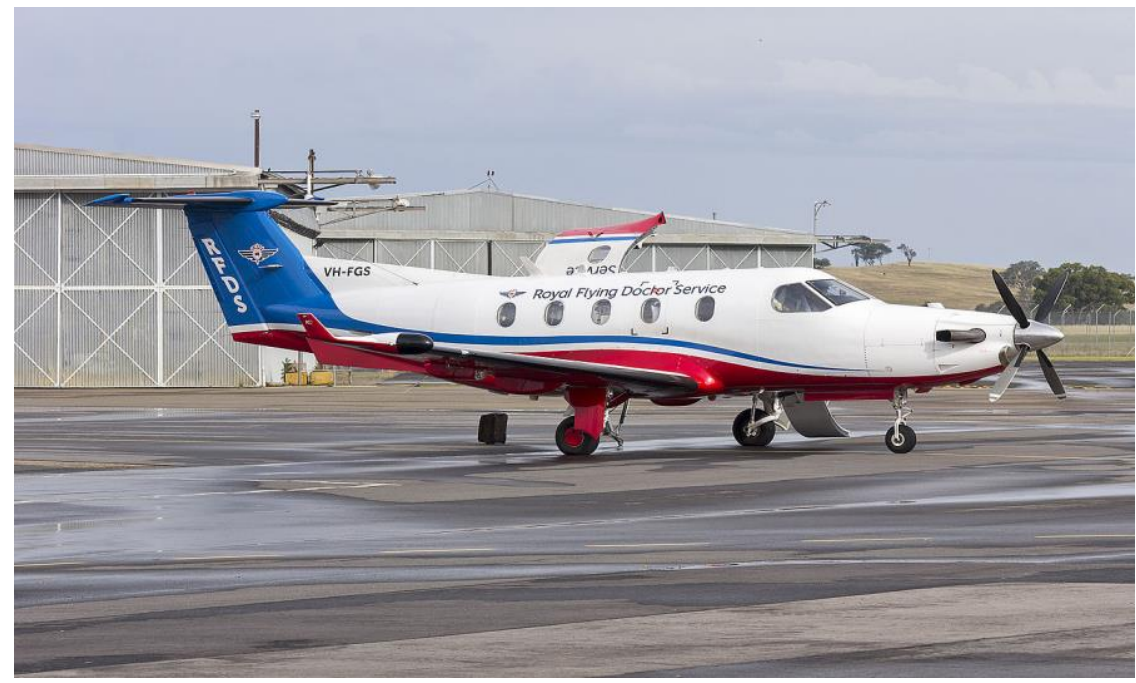

Figure 4. RFDS Pilatus aircraft. Retrieved from google.com.

$\underline{\text { Operations }}$ - model can be based on normal charter/schedule operations, however the medical need will require minor but on-going adjustments. Medical representatives assume this role, because coordination of all personnel in such a system is critical for proper functioning and better healthcare outcomes.

Byproducts of this system will be the establishment or regional laboratories and imaging centers, flight and medical crews training centers, 
maintenance facilities, and more. The positive economic impact of such operations is much more significant than only medical aspects.

\section{Small Airports - Big Impact}

It is hard to underestimate the role of air transport in the modern world. We are not talking about solely economic aspects which easily can be measured (Button, 2009) but also social and psychological benefits which attached to air transport. ICAO (International Civil Aviation Organization) states that in addition to the economic benefits, air transport improves quality of life by broadening people's leisure and cultural experiences. It provides an affordable means to visit distant friends and relatives. Air transport helps to improve living standards and alleviate poverty, for instance, through tourism. Air transport may provide the only transportation means in remote areas, thus promoting social inclusion. Air transportation contributes to sustainable development. By facilitating tourism and trade, it generates economic growth, provides jobs, increases revenues from taxes, and fosters the conservation of protected areas. The air transportation network facilitates the delivery of emergency and humanitarian aid relief anywhere on earth and ensures the swift delivery of medical supplies and organs for transplantation (ICAO, 2019).

In other words, aviation and medicine can have great synergy in developing rural communities and not only resolving medical needs.

\section{Conclusion}

The model offered in this paper based on US reality, but Fly-In clinics can be established in any place in the world with low healthcare accessibility. Modern aviation has almost unlimited abilities to reach places, and beside helicopters, which already proved themselves in search and rescue missions, fixed-wing aircraft can be used not only for retrieval but also as a flying clinic or personnel 
transport of primary and special medicine (like "flying dental office" of RFSD). Modern aircraft are less and less dependent on weather conditions, due to synthetic vision, and advanced computer and navigational systems allow flight crews to extend their flying abilities and to make our world smaller and much more accessible. Aviation-based medical services (other than an emergency) still do not have solid epidemiological basis and development of an explicit model of such operations can be a useful tool in policy planning and responding to changing population trends. This concept can allow bringing experienced and skilled medical personnel to remote areas but to allow them to come home to their families for dinner at the same day, like any other day in the hospital or the office.

***The author has no affiliation to the State of Arizona nor to Royal Flying Doctors Service of Australia. Using Arizona data was for exampling proposes and received from open sources. *** 


\section{References}

Bearak, J. M., Burke, K. L., \& Jones, R. K. (2017). Disparities and change over time in distance women would need to travel to have an abortion in the USA: A spatial analysis. The Lancet. doi.org/10.1016/S24682667(17)30158-5

Button, K., Doh, S., \& Yuan, J. (2009). The role of small airports in economic development. Airport Management, 14(1), 1750-1938.

Datausa. (n.d.). Arizona. Retrieved from https://datausa.io/profile/geo/ arizona\#about

Frey, W. H. (2018). US population disperse to suburbs, exurbs, rural areas and "middle of the country" metros. Retrieved from www.brookings.edu

Gardiner, F. W., Gale, L., Ransom, A., \& Laverty, M. (2017). Looking ahead: Responding to the health needs of the country Australian 2028 - The centenary year of RFDS. Royal Flying Doctors Services. Retrieved from https://www.flyingdoctor.org.au/assets/documents/RN064_Looking_Ahea d_Report_D3.pdf

Google.com. (n.d.). RFDS Pilatus PC-12 aircraft. Retrieved from https://www.google.com/

Gruca, T. S., Pyo, T.H., \& Nelson, G. C. (2016) Providing cardiology care in rural areas through visiting consultant clinics. Journal of AHA. doi.org/10.1161/JAHA.115.002909

International Civil Aviation Organization. (2019). The economic \& social benefits of air transport. Retrieved from www.icao.int

Rural Health Hub. (2019). Visualization. Retrieved from https://www.ruralhealthinfo.org/visualizations

U.S. Department of Health and Human Services. (n.d.). Health resources and services administration. Retrieved Apr. 19, 2019 from www.hrsa.gov 